\title{
EFFECT OF DIFFERENT SUBSTANCES ON SOME PROPERTIES OF SOIL CONTAMINATED WITH HEATING OIL
}

\author{
Mirosław Wyszkowski ${ }^{1}$, Veranika Sivitskaya ${ }^{2}$
}

1 Department of Environmental Chemistry, University of Warmia and Mazury in Olsztyn, 4 Łódzki Sq., 10-727 Olsztyn, Poland, e-mail: miroslaw.wyszkowski@uwm.edu.pl

2 Department of Environmental Chemistry, University of Warmia and Mazury in Olsztyn, 4 Łódzki Sq., 10-727 Olsztyn, Poland, e-mail: veranika.sivitskaya@uwm.edu.pl

Received: 2014.10 .20

Accepted: 2014.11.14

Published: 2015.01.02

\begin{abstract}
The aim of the study was to determine the effect of the application of different substances (nitrogen, compost, bentonite, zeolite and calcium oxide) to soil on its selected properties after prior contamination with heating oil: $0,5,10,15$ and $20 \mathrm{~g} \mathrm{~kg}^{-1} \mathrm{~d}$.m. of soil. Heating oil contamination and the application of different substances had a significant effect on the tested soil properties. In the series without additives, heating oil caused an increase in soil $\mathrm{pH}$ and a decrease in hydrolytic acidity, the total exchange bases and cation exchange capacity. Bentonite and calcium oxide had the strongest effect of all the substances on soil properties. They induced a rise in soil $\mathrm{pH}$, an increase in the total exchange bases and cation exchange capacity and a decrease in hydrolytic acidity. The effect of other substances, particularly nitrogen and compost, on the tested soil properties was significantly lower. On the soil contaminated with heating oil, the effect of individual substances on the degree of base saturation was relatively small because it did not exceed $8 \%$ in all of the test series.
\end{abstract}

Keywords: heating oil contamination, nitrogen, compost, bentonite, zeolite, calcium oxide, soil properties.

\section{INTRODUCTION}

Intensive development of industry, construction and the increase in diverse needs of population in developed countries involves the need to obtain, produce, transport and store rising quantities of fuels [Nadim et al. 2000, Wyszkowski et al. 2004]. Unfortunately, this is not harmless to the environment because of the entailed possibility of its pollution, which is the result of different kinds of events, mainly failures [Nadim et al. 2000]. One of these fuels is heating oil, most often used for heating buildings. If the soil environment is contaminated, the effects can be substantial and sometimes even hard to reverse. Oil derivatives have a very strong effect not only on physicochemical soil properties [Baran et al. 2002, Kucharski, Jastrzębska 2005, Ziółkowska, Wyszkowski 2010], but they also cause a loss of microbiological and biochemical balance in the soil [Wyszkowska, Wyszkowski
2010], which often becomes unfit for plant cultivation. Therefore, it becomes necessary to make an attempt to restore soil balance, e.g. by the application of different kinds of substances, bioremediation and phytoremediation or the use of more costly ex situ methods.

The aim of the study was to determine the effect of the application of different substances (nitrogen, compost, bentonite, zeolite and calcium oxide) to soil on its selected properties after prior contamination with heating oil.

\section{MATERIALS AND METHODS}

The study was performed in the greenhouse of the University of Warmia and Mazury in O1sztyn (north-eastern Poland) on soil with the granulometric composition of loamy sand. The soil properties were as follows: $\mathrm{pH}$ at 1 mole 
$\mathrm{KCl} \cdot \mathrm{dm}^{-3}-4.52$; hydrolytic acidity (HA) -25.4 $\operatorname{mmol}(+) \cdot \mathrm{kg}^{-1}$; the total exchange bases (TEB) $-29.1 \mathrm{mmol}(+) \cdot \mathrm{kg}^{-1}$; cation exchange capacity (CEC) $-54.5 \mathrm{mmol}(+) \cdot \mathrm{kg}^{-1}$; the degree of cation saturation (BS) $-53.4 \%$; $\mathrm{C}_{\text {org }}$ content -11.28 $\mathrm{g} \cdot \mathrm{kg}^{-1}$; the content of available forms of: phosphorus $-71.88 \mathrm{mg} \mathrm{P} \cdot \mathrm{kg}^{-1}$; potassium -118.60 $\mathrm{mg} \mathrm{K} \cdot \mathrm{kg}^{-1}$ and magnesium $-104.18 \mathrm{mg} \mathrm{Mg} \cdot \mathrm{kg}^{-1}$. The soil was contaminated with heating oil in the amounts of: $0 ; 5 ; 10 ; 15$ and $20 \mathrm{~g} \cdot \mathrm{kg}^{-1} \mathrm{DM}$. The study was conducted in five series: without the substances and with the application of nitrogen (200 $\mathrm{mg} \mathrm{N} \cdot \mathrm{kg}^{-1}$ soil in the form of $46 \%$ urea), compost $(3 \%)$, bentonite and zeolite $(2 \%$ relative to soil mass) and $50 \%$ calcium oxide in a dose corresponding to one full hydrolytic acidity. Macro- and micronutrients were also applied to all the pots in the same amounts (in $\mathrm{mg} \cdot \mathrm{kg}^{-1}$ soil): $\mathrm{N}$ $100\left(\mathrm{CO}\left(\mathrm{NH}_{2}\right)_{2}\right), \mathrm{P}-30\left(\mathrm{KH}_{2} \mathrm{PO}_{4}\right) ; \mathrm{K}-100(\mathrm{KH}-$ $\left.{ }_{2} \mathrm{PO}_{4}+\mathrm{KCl}\right) ; \mathrm{Mg}-50\left(\mathrm{MgSO}_{4} \cdot 7 \mathrm{H}_{2} \mathrm{O}\right) ; \mathrm{Mn}-5$ $\left(\mathrm{MnCl}_{2} \cdot 4 \mathrm{H}_{2} \mathrm{O}\right) ; \mathrm{Mo}-5\left[\left(\mathrm{NH}_{4}\right)_{6} \mathrm{Mo}_{7} \mathrm{O}_{24} \cdot 4 \mathrm{H}_{2} \mathrm{O}\right]$; B $-0.33\left(\mathrm{H}_{3} \mathrm{BO}_{3}\right)$. During the establishment of the experiment, heating oil, compost, bentonite and calcium oxide, as well as macro- and micronutrients in a form of aqueous solutions, were mixed with $9 \mathrm{~kg}$ soil and transferred to polyethylene pots. Spring barley (Hordeum vulgare L.) cv. Rebel was sown in the prepared pots as well as white mustard (Sinapis alba L.) cv. Bardena after its harvest in the flowering phase. The moisture content was maintained at $60 \%$ of the capillary water capacity during the study. Soil samples for the tests were collected at the time of white mustard harvest in the flowering phase.

The following were determined in the soil, after prior drying and screening through a $1 \mathrm{~mm}$ mesh sieve: $\mathrm{pH}$ - by the potentiometric method in an aqueous $\mathrm{KCl}$ solution with a concentration of $1 \mathrm{~mole} \cdot \mathrm{dm}^{-3}$, hydrolytic acidity (HA) and the total exchange bases (TEB) - by the Kappen method [Lityński et al. 1976]. Cation exchange capacity (CEC) and the degree of soil base saturation (BS) were computed based on hydrolytic acidity (HA) and the total exchange bases (TEB) by the following formulas: $\mathrm{CEC}=\mathrm{TEB}+\mathrm{HA}$; $\mathrm{BS}=$ $\mathrm{TEB} \cdot \mathrm{CEC}^{-1} \cdot 100$. Moreover, the following were determined in the soil before the experiment was established: organic carbon $\left(\mathrm{C}_{\text {org }}\right)$ content - by the Tiurin method [Lityński et al. 1976], available phosphorus and potassium content - by the Egner-Riehm method [Lityński et al. 1976], available magnesium content - by the Schachtschabel method [Lityński et al. 1976]. A two-factor analy- sis of variance (ANOVA) from the Statistica package [StatSoft, Inc. 2010] and Pearson's simple correlation coefficients (to determine the relationship between soil heating oil contamination and the tested soil properties) were used for statistical analysis of the obtained test results.

\section{RESULTS AND DISCUSSION}

Heating oil contamination and the application of different substances had a significant effect on the tested soil properties (Tables 1 and 2). In the series without additives, $\mathrm{pH}$ was positively correlated with increasing heating oil doses. The $\mathrm{pH}$ rose under increasing heating oil doses in the soil with a dose of $20 \mathrm{~g} \cdot \mathrm{kg}^{-1}$ soil. In the series with the respective additives, the relationship between heating oil doses and $\mathrm{pH}$ was not always so clearly directed as in the series without additives. In the series without additives, hydrolytic acidity in the studied soil decreased under increasing heating oil doses. The highest heating oil dose (20 $\mathrm{g} \cdot \mathrm{kg}^{-1}$ soil) caused a decrease by $22 \%$ compared to the object without the tested oil derivative. The effect of increasing heating oil doses on the total exchange bases and cation exchange capacity was negative. No relationship was detected between increasing heating oil doses and the degree of base saturation for the soil under white mustard.

Contamination of soils with oil derivatives has a significant effect on soil properties. Experiments by Kucharski and Jastrzębska [2005] indicate that heating oil caused a decrease in $\mathrm{pH}$, the sum of base cations, cation exchange capacity and the degree of sorption complex base saturation, which is partly consistent with the results of own research. In a study by Baran et al. [2002], point sources of contamination with oil derivatives induced an increase in $\mathrm{pH}$, the sum of base cations and cation exchange capacity.

All the alleviating substances applied to the soil caused changes in the tested properties in the objects contaminated with heating oil (Figure 1).

Comparing the effect of the substances in the soil contaminated with heating oil in the amount of $5-20 \mathrm{~g} \cdot \mathrm{kg}^{-1}$ soil, $\mathrm{CaO}$ and, to a slightly lower degree, bentonite, showed the most stimulating effect on soil $\mathrm{pH}$ compared to the series without additives. Bentonite and calcium oxide, as the only substances, contributed to a decrease in hydrolytic acidity in the soil by $39 \%$ and $31 \%$, compared to the series without additives (Figure 1). Zeolite and 
Table 1. $\mathrm{pH}$ and hydrolytic activity in soil after plants harvest

\begin{tabular}{|c|c|c|c|c|c|c|c|}
\hline \multirow{2}{*}{$\begin{array}{l}\text { Dose of heating oil } \\
\text { in } \mathrm{g} \cdot \mathrm{kg}^{-1} \text { of soil }\end{array}$} & \multicolumn{7}{|c|}{ Kind of substance neutralizing effect of heating oil } \\
\hline & $\begin{array}{l}\text { Without } \\
\text { additions }\end{array}$ & Nitrogen & Compost & Bentonite & Zeolite & $\mathrm{CaO}$ & Average \\
\hline \multicolumn{8}{|c|}{$\mathrm{pH}$} \\
\hline 0 & 5.34 & 4.76 & 5.11 & 6.84 & 5.35 & 6.33 & - \\
\hline 5 & 5.20 & 5.60 & 5.25 & 6.58 & 5.34 & 6.52 & - \\
\hline 10 & 5.32 & 5.27 & 5.53 & 6.71 & 5.32 & 7.01 & - \\
\hline 15 & 5.40 & 5.23 & 5.34 & 6.65 & 5.46 & 6.95 & - \\
\hline 20 & 5.86 & 5.27 & 5.46 & 6.55 & 5.36 & 6.83 & - \\
\hline r & $0.768^{* *}$ & 0.342 & $0.747^{* *}$ & $-0.683^{*}$ & 0.444 & $0.779^{* *}$ & - \\
\hline \multicolumn{8}{|c|}{ LSD for: heating oil dose $-0.13^{* *} ;$ kind of neutralizing substance $-0.14^{* *} ;$ interaction $-0.31^{* *}$} \\
\hline \multicolumn{8}{|c|}{ Hydrolytic activity [mmol $\cdot \mathrm{kg}^{-1}$ of soil] } \\
\hline 0 & 31.0 & 24.9 & 29.6 & 17.5 & 30.1 & 24.3 & 26.2 \\
\hline 5 & 28.4 & 23.9 & 26.1 & 16.4 & 30.2 & 19.2 & 24.0 \\
\hline 10 & 26.6 & 28.4 & 32.6 & 16.7 & 31.2 & 18.4 & 25.6 \\
\hline 15 & 28.0 & 29.9 & 30.9 & 15.6 & 28.4 & 19.1 & 25.3 \\
\hline 20 & 24.3 & 28.5 & 29.8 & 17.2 & 29.3 & 17.5 & 24.4 \\
\hline Average & 27.7 & 27.1 & 29.8 & 16.7 & 29.8 & 19.7 & 25.1 \\
\hline$r$ & $-0.883^{* *}$ & $0.814^{* *}$ & 0.337 & -0.305 & -0.514 & $-0.820^{* *}$ & -0.419 \\
\hline
\end{tabular}

Explanation: $\mathrm{r}$ - correlation coefficient; significant for: $* *-\mathrm{P} \leq 0.01,{ }^{*}-\mathrm{P} \leq 0.05$.

Table 2. Total exchange bases (TEB), cation exchange capacity (CEC) and base saturation (BS) in soil after plants harvest

\begin{tabular}{|c|c|c|c|c|c|c|c|}
\hline \multirow{2}{*}{$\begin{array}{l}\text { Dose of heating oil } \\
\text { in } \mathrm{g} \cdot \mathrm{kg}^{-1} \text { of soil }\end{array}$} & \multicolumn{7}{|c|}{ Kind of substance neutralizing effect of heating oil } \\
\hline & $\begin{array}{l}\text { Without } \\
\text { additions }\end{array}$ & Nitrogen & Compost & Bentonite & Zeolite & $\mathrm{CaO}$ & Average \\
\hline \multicolumn{8}{|c|}{ Total exchange bases (TEB) [mmol $\cdot \mathrm{kg}^{-1}$ of soil] } \\
\hline 0 & 105.6 & 96.2 & 77.5 & 117.2 & 119.6 & 100.0 & 102.7 \\
\hline 5 & 94.4 & 87.4 & 93.6 & 130.0 & 115.1 & 101.5 & 103.7 \\
\hline 10 & 85.8 & 88.9 & 90.3 & 134.6 & 106.8 & 112.9 & 103.2 \\
\hline 15 & 86.9 & 85.3 & 81.7 & 132.5 & 102.6 & 115.4 & 100.7 \\
\hline 20 & 96.7 & 75.2 & 92.7 & 132.7 & 105.0 & 116.8 & 103.2 \\
\hline Average & 93.9 & 86.6 & 87.2 & 129.4 & 109.8 & 109.3 & 102.7 \\
\hline $\mathrm{r}$ & -0.496 & $-0.920^{* *}$ & 0.410 & $0.756^{* *}$ & $-0.914^{* *}$ & $0.943^{* *}$ & -0.262 \\
\hline \multicolumn{8}{|c|}{ LSD for: heating oil dose - n.s.; kind of neutralizing substance $-6.7^{* *} ;$ interaction $-14.9^{* *}$} \\
\hline \multicolumn{8}{|c|}{ Cation exchange capacity (CEC) [mmol $\cdot \mathrm{kg}^{-1}$ of soil] } \\
\hline 0 & 128.5 & 121.4 & 100.9 & 129.4 & 142.2 & 116.5 & 123.1 \\
\hline 5 & 117.2 & 106.8 & 116.7 & 144.4 & 140.4 & 116.5 & 123.7 \\
\hline 10 & 107.5 & 109.9 & 111.1 & 151.5 & 134.2 & 128.5 & 123.8 \\
\hline 15 & 106.9 & 107.5 & 101.1 & 147.5 & 133.0 & 128.4 & 120.7 \\
\hline 20 & 117.3 & 99.5 & 113.3 & 144.1 & 132.5 & 131.8 & 123.1 \\
\hline Average & 115.5 & 109.0 & 108.6 & 143.4 & 136.4 & 124.3 & 122.9 \\
\hline$r$ & -0.586 & $-0.859^{* *}$ & 0.205 & $0.616^{\star}$ & $-0.941^{* *}$ & $0.924^{* *}$ & -0.391 \\
\hline \multicolumn{8}{|c|}{ LSD for: heating oil dose - n.s.; kind of neutralizing substance $-7.1^{*} ;$ interaction $-15.8^{*}$} \\
\hline \multicolumn{8}{|c|}{ Base saturation (BS) [\%] } \\
\hline 0 & 82.1 & 79.2 & 76.7 & 90.6 & 84.1 & 85.8 & 83.1 \\
\hline 5 & 80.5 & 81.8 & 80.2 & 90.0 & 82.0 & 87.1 & 83.6 \\
\hline 10 & 79.8 & 80.9 & 81.3 & 88.9 & 79.6 & 87.9 & 83.0 \\
\hline 15 & 81.3 & 79.0 & 80.7 & 89.8 & 77.2 & 89.9 & 83.0 \\
\hline 20 & 82.4 & 75.6 & 81.8 & 92.1 & 79.3 & 88.6 & 83.3 \\
\hline Average & 81.2 & 79.3 & 80.1 & 90.3 & 80.4 & 87.9 & 83.2 \\
\hline$r$ & 0.215 & $-0.674^{*}$ & $0.840^{* *}$ & 0.381 & $-0.856^{* *}$ & $0.857^{* *}$ & -0.127 \\
\hline
\end{tabular}

Explanation: $\mathrm{r}$ - correlation coefficient; significant for: ${ }^{* *}-\mathrm{P} \leq 0.01,{ }^{*}-\mathrm{P} \leq 0.05$. 

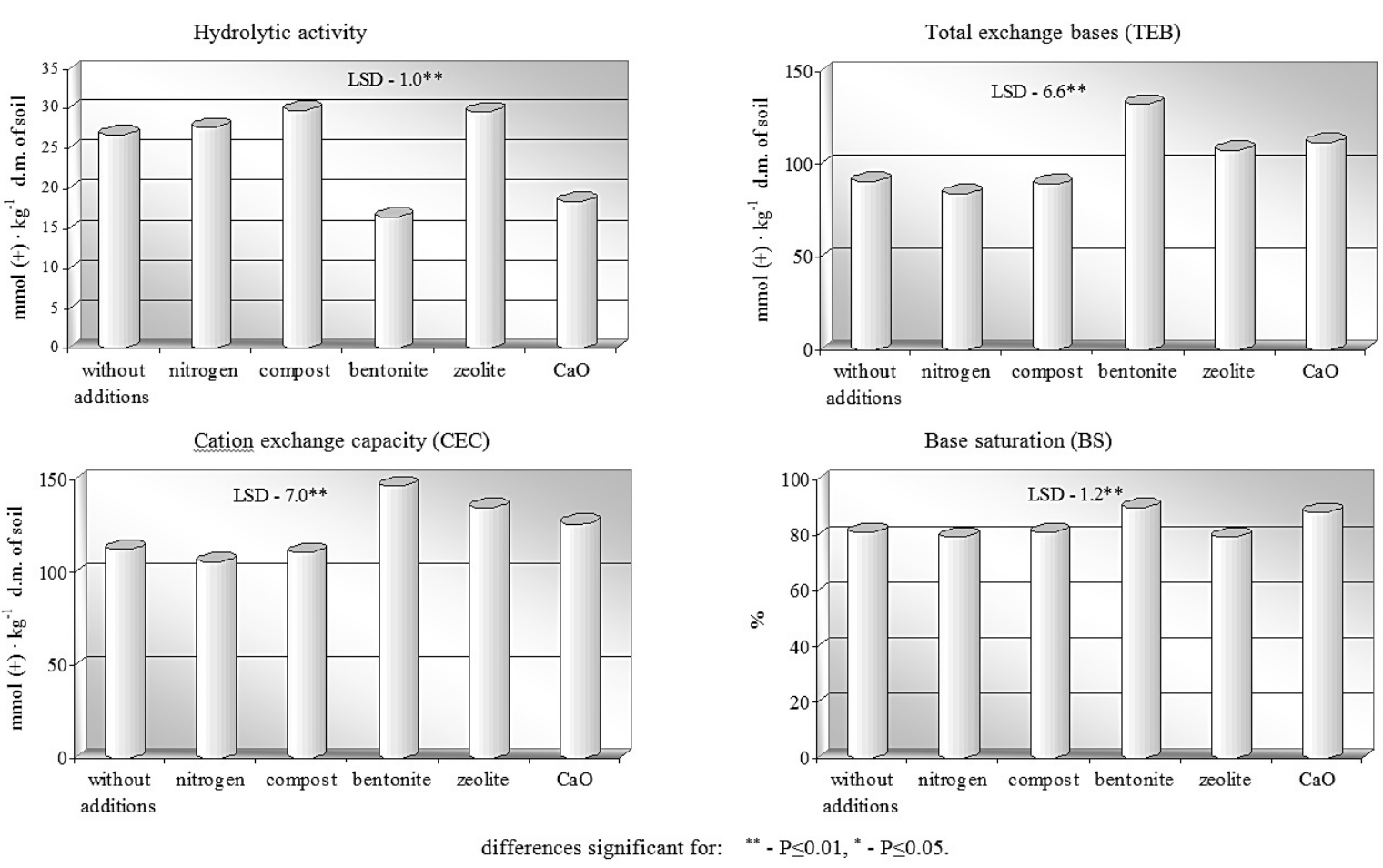

Figure 1. Soil properties after plants harvest (average from series contaminated with 5-20 g heating oil per kg of soil)

compost caused an increase in hydrolytic acidity in the soil, but only by $11 \%$. The addition of nitrogen had no substantial effect on the tested property.

In the soil contaminated with heating oil, bentonite and calcium oxide showed the most stimulating effect and contributed to an increase in the total exchange bases by $46 \%$ and $23 \%$ and in cation exchange capacity by $26 \%$ and $13 \%$ compared to the series without additives (Figure 1). An increase in the total exchange bases by $18 \%$ and cation exchange capacity by $20 \%$ compared to the series without additives was recorded after the application of zeolite.

In the soils contaminated with heating oil, the effect of individual substances on the degree of base saturation was relatively low because it did not exceed 5\% in all the test series (Figure 1). An exception was the application of bentonite and calcium oxide, which increased the value of the tested index by $8 \%$ and $7 \%$, respectively, compared to the series without the alleviating substances.

The application of neutralizing additives to soil usually has a positive effect on the properties of soil contaminated with small quantities of oil derivatives. Organic substances act particularly favorably, as indicated by the studies of Riffaldi et al. [2006], Quintern et al. [2006], Wyszkowski and Ziółkowska [2009]. Organic substances, especially compost, have a positive effect on the sorption properties of soil and accelerate the decomposition of oil derivatives [Ziółkowska, Wyszkowski 2010]. The positive effect of bentonite and $\mathrm{CaO}$ on soil $\mathrm{pH}$ was confirmed by Wyszkowski and Ziółkowska [2011] who found that in soil contaminated with gasoline and diesel fuel these additives contributed to an increase in $\mathrm{pH}$, the total exchange bases and exchange capacity. Bentonite, calcium oxide and compost decreased hydrolytic acidity in contaminated soil and contributed to a rise in the degree of base saturation. This creates more optimal conditions for a proper element cycle in the soil environment and plant growth [Ziółkowska, Wyszkowski 2010]. When soil is highly contaminated with oil derivatives, plant cultivation is not possible [Ogboghodo et al. 2004].

\section{CONCLUSIONS}

1. Heating oil contamination and the application of different substances had a significant effect on the tested soil properties.

2. In the series without additives, heating oil caused an increase in soil $\mathrm{pH}$ and a decrease in hydrolytic acidity, the total exchange bases and cation exchange capacity.

3. Bentonite and calcium oxide had the strongest effect of all the substances on soil properties. They induced a rise in soil $\mathrm{pH}$, 
an increase in the total exchange bases and cation exchange capacity and a decrease in hydrolytic acidity.

4. The effect of the other substances, particularly nitrogen and compost, on the tested soil properties was significantly lower. On the soil contaminated with heating oil, the effect of individual substances on the degree of base saturation was relatively small because it did not exceed $8 \%$ in all of the test series.

\section{Acknowledgements}

The study was completed as a part of research funded by the Polish National Science Centre (NCN) No. N N305 305340.

\section{REFERENCES}

1. Baran S., Bielińska E.J., Wójcikowska-Kapusta A. 2002. Kształtowanie się aktywności enzymatycznej w glebach zanieczyszczonych produktami ropopochodnymi. Acta Agroph., 70, 9-19.

2. Kucharski J., Jastrzębska E. 2005. Effects of heating oil on the count of microorganisms and physico-chemical properties of soil. Polish J. Environ. Stud., 14(2), 189-198.

3. Lityński T., Jurkowska H., Gorlach E. 1976. Analiza chemiczno-rolnicza. PWN, Warszawa, 129-132.

4. Nadim F., Hoag G.E., Liu Sh., Carley R.J., Zack P. 2000. Detection and remediation of soil and aquifer systems contaminated with petroleum products: an overview. J. Petroleum Sci. Eng., 26, 169-178.
5. Ogboghodo I.A., Erebor E.B., Osemwota I.O., Isitekhale H.H. 2004. The effects of application of poultry manure to crude oil polluted soils on maize (Zea mays) growth and soil properties. Environ. Monit. Assessm., 96(1-3), 153-161.

6. Quintern M., Lein M., Joergensen R.G. 2006. Changes in soil-biological quality indices after long-term addition of shredded shrubs and biogenic waste compost. J. Plant Nutrit. Soil Sci., 169(4), 488-493.

7. Riffaldi R., Levi-Minzi R., Cardelli R., Palumbo S., Saviozzi A. 2006. Soil biological activities in monitoring the bioremediation of diesel oil-contaminated soil. Water Air Soil Pollut., 170(1-4), 3-15.

8. Statsoft Statistica 10.0 (data analysis software system). www.statsoft.com; 2012.

9. Wyszkowska J., Wyszkowski M. 2010. Activity of dehydrogenases, urease and phosphatases in soil polluted with petrol. J. Toxicol. Environ. Heal. A, 73(17), 1202-1210.

10. Wyszkowski M., Wyszkowska J., Ziółkowska A. 2004. Effect of soil contamination with diesel oil on yellow lupine field and macroelements content. Plant Soil Environ., 50, 218-226.

11. Wyszkowski M., Ziółkowska A. 2011. Effect of compost, bentonite and $\mathrm{CaO}$ on some properties of soil contaminated with petrol and diesel oil. Ecol. Chem. Eng., A, 18 (9-10), 1373-1381.

12. Wyszkowski, M., Ziółkowska, A. 2009. Role of compost, bentonite and calcium oxide in restricting the effect of soil contamination with petrol and diesel oil on plants. Chemosphere 74, 860-865.

13.Ziółkowska A., Wyszkowski M. 2010. Toxicity of petroleum substances to microorganisms and plants. Ecol. Chem. Eng. S, 17(1), 73-82. 